\title{
Hyperproduction Hydrogenic of STH Patology Generation of Clinical - paraclinical Disorders
}

\author{
ELENA IONESCU1*, ANCA CHIRITA, BOGDAN VIRGIL COTOI**, ANCA GANESCU² \\ 'University of Medicine and Pharmacy, 2 Petru Rares Str., 200349, Craiova, Romania \\ ZUniversity of Craiova, Faculty of Science, Department of Chemistry, 107i Calea Bucuresti, 200478, Craiova, Romania
}

\begin{abstract}
Pituitary adenomas are benign tumors ; they arise from epithelial pituitary cells and they represent 10-15\% of intracranial tumors. They can be found at $3 \%$ up to $20 \%$ of the population, on autopsy series. Cephalalgia is a precocious symptom which keeps going over the disease. The aspect as a whole of the person who suffers from this disease in the phase of established malady is characteristic: a very flat-shaped body, massive and stubby thus justifying the comparison with a pachyderm. Hands and legs are disproportionally bigger, like paddles, facies is disharmonic, facial features become coarse, with oblate forehead and massive prominent pregnant mandible. The joints disproportionately bigger, have limited, painful movement. The patient also presents visceral hypertrophy with numerous dysfunctions from various apparatus and systems.
\end{abstract}

Keywords: pituitary adenoma, STH hyposecretion, dysmorphism, acromegaly, visceromegaly

Pituitary adenomas are benign tumors from the epithelial pituitary cells and they represent $10-15 \%$ of intracranial tumors. They can be found at $3 \%$ up to $20 \%$ of the population, on autopsy series [1,2]. These tumors can be hormonally active; they clinically manifest by acromegaly (excessive secretion of growth hormone), Cushing syndrome (ACTH and secondary of cortisol excess), amenorrhea-galactorrhea syndrome (prolactine excess) or it can be hormonally inactive (dysfunctional clinical tumors) [3,4]. Furthermore, pituitary adenomas can grow to sizes which can determine compression effects over the neighbouring structures, defending the pituitary insufficiency, vision disorders and, rarely, intracranial hypertension. From the historical point of view pituitary tumors are mostly benign. The adenoma secreted by PRL or prolactine is the mostfrequent type of secretive pituituray tumor (about 39\%), followed by GH secretive adenomas and ACTH secretive tumors. Non-functional tumors represent only $10 \%$ of pituitary adenomas whereas TSH secreting tumors, gonadotrophines or alpha subunits are rare [5]. Regarding the age of apparition, the pituitary hypersomatotropism determines two distinctive clinical forms: gigantism, when it appears in childhood and acromegaly when it appears after the bones overgrowth. Acromegaly has a gradual slow progressive evolution [68]. Cephalalgia is a precocious symptom which maintains over the disease. The aspect as a whole of the person who suffers from this disease in the phase of established malady is characteristic: a very flat-shaped body, stubby and massive thus justifying the comparison with a pachyderm. Hands and legs are disproportionally bigger, like paddles, the facies is disharmonic, facial features become coarse with oblate forehead, massive prominent pregnant mandible. Although the muscular system is well developed, muscular force is diminished. The joints disproportionately bigger, have limited, painful movement. The patient also presents visceral hypertrophy with numerous dysfunctions from the various systems [12].

\section{Experimental part}

This study was performed at Craiova Emergency County Hospital, having a retrospective component (after observation files) and a perspective one (by direct supervision), over a 6 years period [9]. Within the study there were included 80 patients with pituitary adenomas27 prolactinomas, $19 \mathrm{GH}$ secreting adenomas and 34 nonsecreting tumors.

The patients were investigated by determining the STH, taking usual blood analyses and also evaluating the breathing function and making a cardiovascular, neurological, ophthalmological, psychological evaluation and CT or RMN examination of the GH secreting pituitary tumor. For the 19 patients diagnosed with acromegaly, GH dosing was performed, resulting in values higher than the upper limit (ie above $5 \mathrm{ng} / \mathrm{mL}$ in men or over $10 \mathrm{ng} / \mathrm{mL}$ in women).

Although the high diagnostic accuracy of IGF1 (greater than baseline $\mathrm{GH}$ ) is known, we did nothave this possibility in our study. There are cases of normal and elevated IGF1 acromegaly in the literature. This imposes the introduction of this criterion as a method routine in studying acromegaly

After some authors with experience in the management of patients with acromegaly, diagnosis can only be missed if only criteria based on GH values are used. For diagnosis and monitoring of acromegals, GH should be used along with the serum titer of IGF1 [10].

In acromegaly patients, GH media was $20.96 \mathrm{ng} / \mathrm{mL}$, with a minimum of $6.8 \mathrm{ng} / \mathrm{mL}$ and a maximum of $72.7 \mathrm{ng}$ / $\mathrm{mL}$

It is described in literature the inconsistency between $\mathrm{GH}$ (sometimes small) values and clinical appearance.

Dosing technique - methods for dosing the straight (hormone of growth)

hGH (somatotropin) is essential in the growth process, and in adults it plays an important role in metabolic activities. It is synthesized in the acidophilic cells of the anterior pituitary and its secretion from the intracellular storage granules is regulated by hormone-releasing hormone (GHRH) hormones and SRAT (somatotropin release-inhibiting factor); their synthesis depends on neurotransmitters, such as serotonin, dopamine, norepinephrine, and growth hormone releasing peptides.

It is also secreted in response to effort, stress, deep sleep, hypoglycemia, glucagon, insulin, thyroid hormones,

*email elena.ionesc@yahoo.com; bogdan2303776@yahoo.ro All authors with equal contributions. 
estrogen, testosterone and vasopressin. Plasma exists in several monomeric and oligomeric isoforms (big GH and big big $G H$ ). Circulating $\mathrm{GH}$-binding protein, which is similar to the extracellular domain of the tissue receptor of hGH5.

hGH stimulates the production of RNA, protease synthesis, mobilizes fatty acids from deposits and has transient insulin antagonist effects; elevated prolonged levels may induce alteration of glucose tolerance [5].

The secretion of hGH is pulsatile, but in adults plasma concentrations are stable, hGH oscillations are attenuated by GHBP. The plasma half-life is $20 \mathrm{~min}$ [5].

If the pituitary secretion of $\mathrm{hGH}$ is deficient or excessive in different stages of growth, it will determine the occurrence of nanism and gigantism. An excess of adult growth hormone will generate acromegaly.

The test is useful for confirming hypo- or hyperpituitarism, so that appropriate therapy can be initiated as soon as possible.

Determination of the hormone can be performed under both basal and post stimulation conditions (exercise, arginine, glucagon or insulin) or suppression (after $100 \mathrm{~g}$ of glucose).

Absence of response or inadequate response to stimulation tests is associated with hypopituitarism.

In case of gigantism or acromegaly, there is a lack of suppression or incomplete suppression after glucose administration. Furthermore, patients with acromegaly may have paradoxical increases in hGH in the suppression testl.

Patient training - junction (fasting) and after at least 30 minutes of rest, to determine the basal concentration3;

Harvested specimen - venous blood 3

Vacuum container without anticoagulant, with / without separator gel.

Processing required after harvest - separate the serum by centrifugation; work the serum immediately; if this is not possible, the serum freezes;

Sample volume - minimum $0.5 \mathrm{~mL}$ ser.

Method - immunoenzymatic with chemiluminescent detection .

1)

Reference values - are age and sex dependent (tabel

Table1

REFERENCE VALUES OF hGH

\begin{tabular}{|c|c|}
\hline Age and sex & Reference values $(\mathrm{ng} / \mathrm{mL}$ ) \\
\hline $\begin{array}{l}\text { Adults } \cdot \text { Women } \\
<60 \text { years }\end{array}$ & $<10$ \\
\hline - Women $>60$ ani & $1-14$ \\
\hline$\approx 60$ ani $\cdot$ Men & $<5$ \\
\hline$>60 \mathrm{ami} \cdot \operatorname{men}$ & $0.4-10$ \\
\hline Newboms & $15-40$ \\
\hline children & $<20$ \\
\hline \multirow{2}{*}{ After stimulation } & $\begin{array}{l}>5 \text { (growth compared to } \\
\text { basal level) }\end{array}$ \\
\hline & $>10$ (maximum response to basal level) \\
\hline After suppression & $<2$ \\
\hline
\end{tabular}

Conversion factor: $\mathrm{ng} / \mathrm{mL}=\mu \mathrm{g} / \mathrm{L}$.

Detection limit - 0.01ng / $\mathrm{mL}$

Limits and interferences

A single determination of $h \mathrm{GH}$ has a limited value due to marked fluctuations in serum concentration. Stimulation or suppression tests provide much more information.

Elevated levels can be met postprandial, after physical activity, deep sleep, stress, anxiety, sex hormone deficiency, especially androgens, hypo-, hyperthyroidism, adrenal hyperfunction, increased levels of free fatty acids; low levels can occur in hunger, cachexia, protein deficiency, metabolic imbalance diabetes.

\section{Results and discussions}

Recent studies mention a 1/1 women/men proportion for the $\mathrm{GH}$ secreting adenomas, but in this study we registered 11 women and 8 men with $\mathrm{GH}$ secreting adenomas (fig. 1).

Regarding distribution on age groups specific studies showed that the ocurrence of investigated pathology is more frequent for the age group of 40 - 60 years. In our study we found 4 cases (5\%) with ages between $40-49$ years, 7 cases $(8.75 \%)$ with ages between 50 - 59 years, and only 3 cases ( $3.75 \%$ ) with ages between 30 -39 years, no patient below 30 years and the rest of 5 cases with ages over 60 years (fig. 2).

As for the 19 patients diagnosed with acromegaly there has been performed $\mathrm{GH}$ dosing and as a result there were higher values than the upper limit (over $5 \mathrm{ng} / \mathrm{mL}$ for men or over $10 \mathrm{ng} / \mathrm{mL}$ for women). At the acromegalic patients The $\mathrm{GH}$ average was $20.96 \mathrm{ng} / \mathrm{mL}$, with a minimum of $6.8 \mathrm{ng} / \mathrm{mL}$ and a maximum of $72.7 \mathrm{ng} / \mathrm{mL}$.

From the graphic below (fig.3) we can conclude that there is a direct correlation between the dimension of the tumor measured RMN and somatotrope secretion (the bigger diameter of the tumor is, the bigger is the quantity

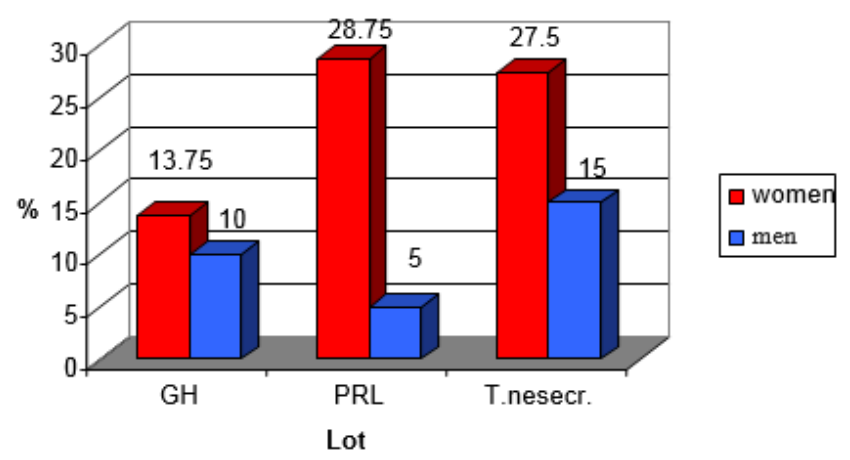

Fig 1. Gender and pathology distribution of subjects in the tumor group

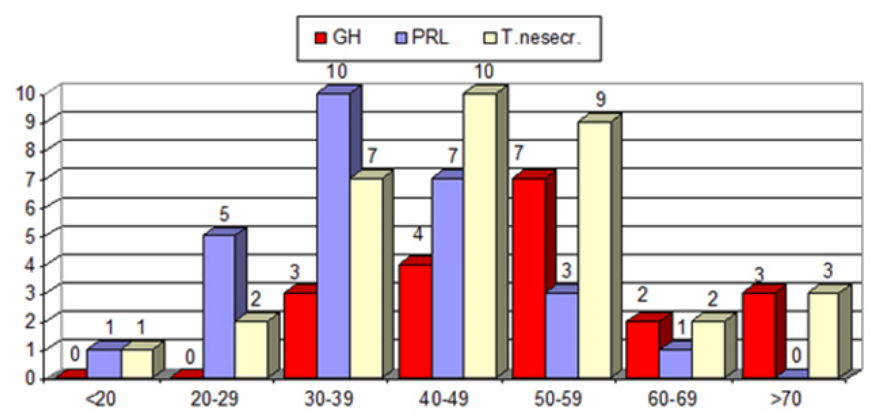

Fig.2. Distribution by age group of the tumor group 


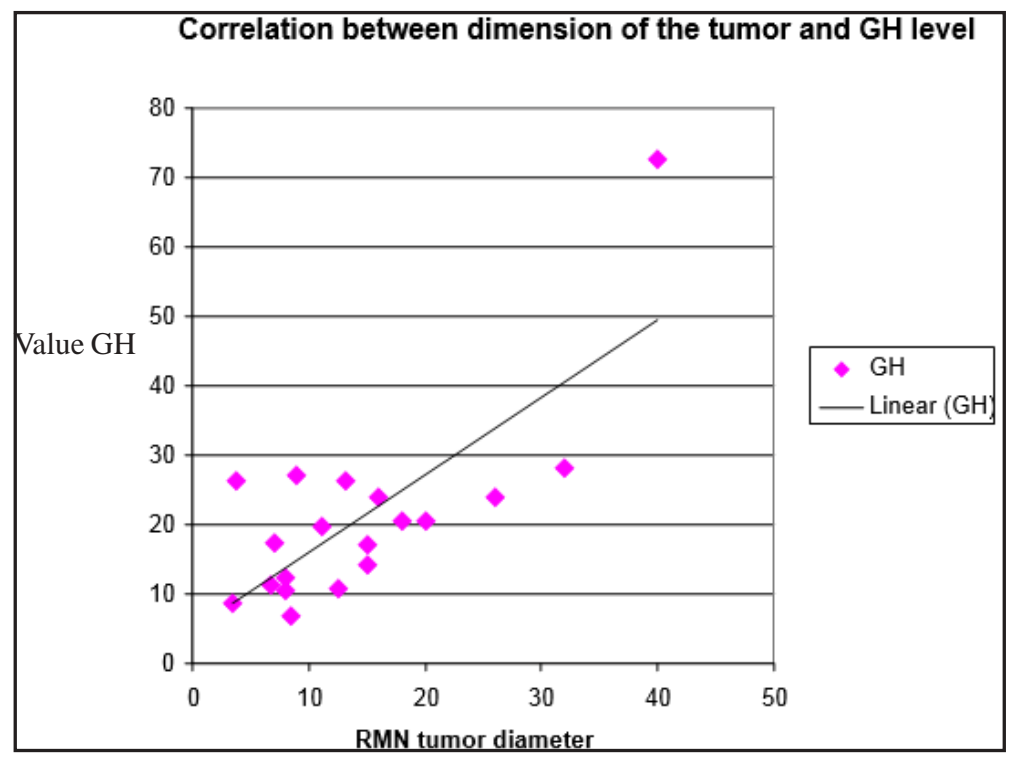

Fig.3. Correlation between hormonal secretion and tumoral volume

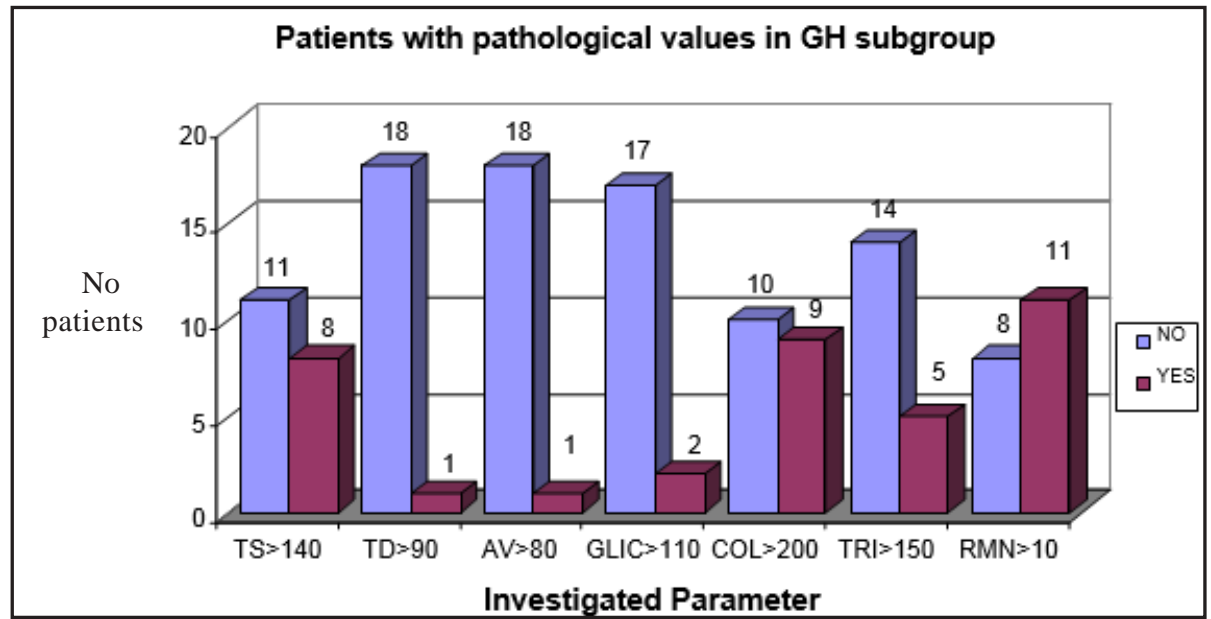

Fig. 4. Pathological values at acromegalic patients

of hormone), because the line of regression has a clear upward slope. This is underlined also statistically, the $r$ correlation coefficient of Pearson having the value of 0.752 , which overcomes the limit of significance of \pm 0.456 of $r$ for 19 subjects (17 freedom degrees). Within the acromegaly pacients group we have obtained the following pathological values (fig.4) :

- Systolic HTA at 8 patients (57.9\%) and diasistolic HTA at 1 patient $(5.3 \%)$;

-AV over 80 beats /min at 1 patient (5.3\%);

-Glycemia over $110 \mathrm{mg} / \mathrm{dL}$ at 2 patients (10.5\%), with diabetes mellitus type II confirmed at 1 patient;

-Hypercholesterolemia at 9 patients (47.4\%);

-Hypertriglyceridemia (triglycerides over $150 \mathrm{mg}$ ) at 5 patients $(26.3 \%)$;

-11 patients ( $57.9 \%$ ) had GH secretive macroadenoma $\mathrm{GH}$ and 8 patients (42.1\%) had microadenoma (smaller than $10 \mathrm{~mm}$ diameter).

Regarding the patients from the present study, the percentage of those whose visual field was affected ( $8.75 \%$ representing 7 patients) is comparable to that whose patients didn't have any CV deficits-8 patients and visual acuity decrease was registered at $46.25 \%$ of the acromegalic patients [16].

From the 19 patients diagnosed with acromegaly, only 1 patient didn't have an EKG print, 4 patients (5\%) had cardiomegaly with associative ischemic cardiopathy, 5 patients (6.25\%) had ischemic cardiopathy symptoms but 9 patients (11.25\%) had an EKG track of normal repose. [15] study there can be seen a three times growth of mortality from breathing causes. Functional breathing tests are abnormal not only at men but also at women. Total pulmonary capacity increases up to $81 \%$ at men and $56 \%$ at women, $36 \%$ present a narrowing of small pipes and $26 \%$ have their large bronchias narrowed. (155) Pipes' narrowing and apnea during sleeping, frequent at these patients, contributes to a high level of mortality at acromegalic patients $[11,12]$ In this study, 18 patients out of 19 , took the breathing functional exploration test. Patients were tested by using spirographic method, measuring the maximum exhaling volume per second (MEVS). After measuring the MEVS there resulted: 10 patients ( $52 \%$ of acromegalic people) didn't have a ventilation dysfunction of gentle obstructive type and 2 patients (11\%) had a medium ventilation dysfunction [13] Depressive disorders and other kinds of disorders associated to acromegaly were: $10 \%$ of $\mathrm{GH}$ secretive pituitary tumor had a severe depression (closely related to present dysmorphism at these patients) $6.25 \%$ had an average depression, $5 \%$ a light depression and only $2.5 \%$ didn't present any symptoms of depression. The risk of depression at the acromegalic patients is higher than the risk of this psychiatric manifestation at other pituitary affections. Other symptoms noticed at acromegalic patients were: psycho-emotional lability, physical and psychical asthenia, loss of initiative, inhibition, tendency of social isolation, mnestic and prosex difficulties, insomnia/ terrifying dreams, irritability, depressive ideation, panic attack, fatigue, anxiety, hallucinations [14]. 


\section{Conclusions}

As for the frequency, adenoma secreted by $\mathrm{GH}$ represents the second type of pituitary adenoma after prolactinoma being characterized by clinical dysmorphism and multivisceral affectation.

Within the studied group we had 11 women and 8 men with a frequent incidence of age group 40-60 years.

There was a direct correlation between the dimension of the tumor measured RMN and somatotrope secretion (the larger is the diameter of the tumor the bigger is the quantity of the hormone).

$85 \%$ of the patients had systolic HTA, 1 patient (5.3\%) had HTA diastolic, diabetes mellitus type 2 was found at 1 patient and dyslipidemia was presented at 9 patients.

\section{References}

1.BISTRICEANU, M., Endocrinologie clinica, Ed. de Sud, Craiova, 2000. 2.DORSHKIND, K.,HORSEMAN ND. The roles of prolactin, growth hormone, insulin-like growth factor-1, and thyroid hormones in lymphocyte development and function: insights from genetic models of hormone and hormone receptor deficiency. Endocr Rev 2000 J un; 21:292-312.

3.DIMARAKI ,EV.,J AFFE, CA ,, DEMOTT, FRIBERG R.,ET ALL Acromegaly apparently normal Gh secretion: implication for diagnosis foolow up. J Clin Endocrinol Metab 2002:87;3537-3542.

4.FREDA PU, REYES CM, NURUZZAMAN AT, ET AL. Basal and glucosuppressed GH levels less than $1 \mu \mathrm{g} / \mathrm{L}$ in newly diagnosed acromegaly. Pituitary 2003;6:175-180.

5.HERRMANN ,B.L., BRUCH ,C., SALLER ,B., BARTEL, T., FERDIN, S., ERBEL, R., MANN, K: Acromegaly evidence for a direct relation between disease activity and cardiac dysfunction in patients without ventricular hypertrophy. Clin Endocrinol 2002;56:595-602.

6.J AFFRAIN-REA ,ML., MORONI, C., BALDELLI, R., ET AL: Relationship betw een blood pressure and glucose tolerance in acromegaly. Clinical Endocrinology (0xf), 2003;54(2): 189-195. Ref. Type: Generic.
7.KATZNELSON ,LAURANCE: The diagnosis and treatment of acromegaly. The endocrinologist. 2003;13-428-434.

8.ORUCKAPTAN, HH., SENMEVISM, O., OZCAN, OE., ET AL: Pituitary adenomas: results of 684 surgically treated patients and review of the literature. Surg Neurol 2000, 53:211-219.

9.POPOVIC ,V., LEAL, A., MICIC ,D., ET AL. GH-releasing hormone and GH-releasing peptide- 6 for diagnostic testing in GH-deficient adults. Lancet 2000;356:1137-1142

10.IONESCU, E..,Teza de doctorat-Evaluarea capacitatii de munca la pacientii cu patologie hipofizara.Craiova 2011.

11.IONESCU, E., Ghid de evaluare clinic-biologica a pacientilor cu patologie hipofizara, Editura Techirghiol Craiova 2015

12. MIHAELA, N. POPESCU, ELENA, IONESCU, L. C .,IONESCU, B. V., COTOI, A.I. POPESCU, ANCA ,ELENA ,GANESCU., ADINA, GLODEANU., CRISTINA. GEORMÃNEANU ,ANDREIANA,MORARU.,ANCA, PÃTRASCU., Clinical aggression of prolactinomas: correlations with invasion and recurrence, Romanian J ournal of Morphology and Embryology, Romanian Academy Publishing House, Volume 54, 2013, ISSN (print) 1220-0522, ISSN (on line) 2066-8279.

13. GANESCU,A., MURESEAN, M., IONESCU, E., et all, New Methods for Claritine Determination Based on Pt(IV) Complex Anions, Rev.Chim.(Bucharest),65 , no.5, 2014, p. 512-515

14. MAVRITSAKIS ,NIKOLAOS., URSU, VASILE EMIL., ELENA IONESCU., ANCA GANESCU, Actual Study Regarding Quantitative Determination of Tetracyclines by Electrical Analysis Techniques and Methods Potentiometric sensors for tetracycline Rev.Chim.(Bucharest),70, no. 2,2019, p. 671-675

15. MAVRITSAKIS, N., URSU, V.E., IONESCU, E., GANESCU, A., Clinical and Biological Study on the Relevance of Hiperfibrinogenemyme in Cardiovascular Pathology of the Obez Patient, Rev.Chim. (Bucharest), 70,no. 3 ,2019, p. 950-955.

16.,POPESCU.,I.G., SECHEL.G., ,LEASU.F.G., TANTU., M.M.,,COTOI., B.V., ROGOZEA, L.M.,Correlations on the protection of personal data and intellectual property rights in medical research,Rom.J. Morphol.Embryol,59(3),2018,pag 1001-1005.

Manuscript received: 6.11 .2018 